\title{
Brief Report: Response to National Institutes of Health Report
}

\author{
Temple Grandin ${ }^{1}$ \\ Department of Animal Science, Colorado State University
}

The report was a good document but unfortunately it did not adequately address the need to do research on sensory problems in autism. As a person with autism I am very concerned about this. A better understanding of sensory problems will lead to more effective treatments. Research in this area will explain why an intensive behavior program, such as that proposed by Lovaas (1987), will work with one child and fail with another. There is also a need to research the best therapies for sensory dysfunction.

Sensory processing and attention shifting are abnormal in autism (Ciesielski, Courchesne, \& Elmasian, 1990; Ornitz 1985; WainwrightSharp \& Bryson, 1993). Certain types of sensory input such as flickering fluorescent lights will increase repetitive behavior (Colman, Frankel, Ritvo, \& Freeman, 1976). Reports from people with autism clearly show that sights, sounds, and sensations that do not bother normal people may be painful and confusing. Sound sensitivity and intense discomfort caused by certain sounds is reported frequently (Bemporad, 1979; Grandin, 1992a, 1995; Grandin \& Scariano, 1986; Stehli, 1991; White \& White, 1987). Autistics also report that they sometimes have difficulty understanding speech and that hearing may fade in and out (Jolifee, Lakesdown, \& Robinson, 1992; Williams, 1994; Sinclair, 1992; White \& White, 1987). An auditory training treatment which consists of listening to electronically modified music has reduced sound sensitivity and decreased behavior problems in individuals with autism (Rimland \& Edelson, 1994, 1995).

Teachers and parents both maintain that sensory integration therapy is helpful. The method was developed by Ayres (1979) and consists of ap-

${ }^{1}$ Address all correspondence to Temple Grandin, Department of Animal Science, Colorado State University, Fort Collins, Colorado 80523. 
plication of deep pressure and games in which a child is spun or swung. Vestibular stimulation from swinging will often enable autistic children with poor language skills to verbalize and make speech sounds (Ray, King, \& Grandin, 1988). Bhatera, Clark, Arnold, Gunsett, and Smeltzer (1981) found that spinning a child in a chair twice a week reduced hyperactivity. Pressure applied to the body has a calming effect on both people and animals (Grandin, 1992b; Grandin, Dodman, \& Shuster, 1989; Kumazawa, 1963; Mclzack, Konrad, \& Dubrowsky, 1969; Tagaki \& Kobagasi, 1956). Grandin and Scariano (1986) and McKean (1994) both report that application of pressure on large areas of their body relieved anxiety and sensory discomfort. Self-stimulatory behaviors can be reduced by wearing a garment that applies pressure (McClure \& Holtz, 1991: Zisserrnnan, 1992). Exercise is also helpful (Elliot, Dobbin, Rose, \& Soper, 1994).

Some individuals with autism also have problems with sensory mixing between modalities. They can attend to only one sensory modality at a time (Cesaroni \& Garber, 1991; Sinclair, 1992; Williams, 1994). They have difficulty seeing and hearing at the same time. Sensory mixing and overload of an immature sensory processing system may explain why intensive behavioral programs work for one child and fail in another. Williams (personal communication) told me that forcing eye contact caused her brain to shut down.

Anecdotal reports indicate that sensory methods of treatment are effective. Pressure, swinging on a swing, or auditory training may improve sensory processing so that more accurate information can get through to the child's brain. Sensory treatments are not substitutes for other educational programs. They should be used in conjunction with other programs to improve effectiveness. Research is needed to develop the most effective methods for diagnosing and treating sensory processing dysfunction.

\section{REFERENCES}

Ayres, J. A. (1979). Sensory integration and the child. Western Psychological Services, Los Angeles.

Bemporad, J. R. (1979). Adult recollections of a formerly autistic child. Journal of Autism and Developmental Disorders, 9, 179-197.

Bhatera, V., Clark, D. L., Arnold, L. E., Gunsett, R., \& Smeltzer, D. J. (1981). Hyperkinesis treated with vestibular stimulation: An exploratory study. Biological Psychiatry, 16, 269-279.

Cesaroni, L., \& Garber, M. (1991). Exploring the experience of autism through first person accounts, Journal of Autism and Developmental Disorders, 21, 303-312.

Ciesielski, K. T., Courchesne, E., \& Elmaslan, R. (1990). Effects of focused selective attention-tasks, on event-related potentials in autistic and normal individuals. Electroencephalography and Clinical Neurophysiology, 75, 207-220. 
Colman, R. S., Frankel, F., Ritvo, E., \& Freeman, B. J. (1976). The effects of fluorescent and incandescent illuminations upon repetitive behaviors in autistid children. Journal of Autism and Childhood Schizophrenia, 6, 157-162.

Elliot, R. O., Dobbin, A. R., Rose, G. D., \& Soper, H. V. (1994). Vigorous aerobic exercise versus general motor training effects on maladative and stereotypic behavior of adults with autism and mental retardation. Journal of Autism and Developmental Disorders, 24, 565-576.

Grandin, T. (1992a). An inside view of autism. In E. Schopler \& G. B. Mesibov (Eds.), High functioning individuals with autism (pp. 105-126). New York: Plenum Press.

Grandin, T. (1992b). Calming effects of deep pressure in patients with autistic disorder, college students and animals. Journal of Child and Adolescent Psychopharmacology, 2, 63-72.

Grandin, T. (1995). Thinking in pictures, New York: Doubleday.

Grandin, T., Dodman, T. N., \& Shuster, L. (1989). Effect of naltrexone on relaxation induced by lateral flankupressure in pigs. Pharmacology and Biochemistry of Behavior, 33, 839-842.

Grandin, T., \& Scariano, M. (1986). Emergence Labelled Autistic. Novato, CA. Arena.

Joliffe, T., Lakesdown, R., \& Robinson, C. (1992). Autism: A personal account. Communication National Autistic Society of England, 2.6(3), 12-19.

Kumazawa, T. (1963). "Deactivation" of the rabbit's brain by pressure application of the skin. Electroencephalography and Clinical Neurology, 15, 660-671.

Lovaas, I. (1987). Behavioral treatment and normal educational and intellectual functioning in young autistic children. Journal of Consulting and Clinical Psychology, 55, 3-9.

Melzack, R., Konrad, W. K., \& Dubrobsky, B. (1969). Prolonged changes in the central nervous system produced by somatic and reticular stimulation. Experimental Neurology, 25, 416-428.

McClure, M. K., \& Holtz, M. (1991). The effects of sensory stimulatory treatment on an autistic child. American Journal of Occupational Therapy, 45, 1138-1142.

Ornitz, E. (1985). Neurophysiology of infantile autism. Journal of the American Academy of Child Psychiatry, 24, 251-262.

Ray, T. C., King, L. J., \& Grandin, T. (1988). The effectiveness of self initiated vestibular stimulation in producing speech sounds in an autistic child. Journal of Occupational Therapy Research, 8, 186-190.

Rimland, B., \& Edelson, S. (1994). The effects of auditory integration training in autism. Journal of Speech and Language Pathology, 5, 16-24.

Rimland, B., \& Edelson, S. (1995). Auditory integration training: A pilot study. Journal of Autism and Developmental Disorders, 25, 61-70.

Sinclair, J. (1992). Bridging the gap: An inside view of autism. In E. Schopler \& G. B. Mesibov (Eds.), High functioning individuals with autism (pp. 293-302). New York: Plenum Press.

Stehli, A. (1991). Sound of a miracle. New York: Doubleday.

Takagi, K., \& Kobagasi, S. (1956). Skin pressure reflex. Acta Medica et Biologica, 4, 31-37.

Wainwright-Sharp, J. A., \& Bryson, S. E. (1993). Visual orienting deficits in high functioning people with autism. Journal of Autism and Developmental Disorders, 23, 1-12.

White, D. B., \& White, M. S. (1987). Autism from the inside. Medical Hypothesis, 24, 223-229.

Williams, D. (1994). Somebody somewhere. New York: Time Books.

Zisserrnann, L. (1992). The effects of deep pressure on self-stimulating behaviors in a child with autism and other disabilities. American Journal of Occupational Therapy, 46, 547-551. 
